\title{
DOC-dynamics in a small headwater catchment as driven by redox fluctuations and hydrological flow paths - are DOC exports mediated by iron reduction/oxidation cycles?
}

\author{
K.-H. Knorr \\ Limnological Research Station and Department of Hydrology, University of Bayreuth, 95440 Bayreuth, Germany \\ Correspondence to: K.-H. Knorr (kh.knorr@uni-bayreuth.de)
}

Received: 27 August 2012 - Published in Biogeosciences Discuss.: 19 September 2012

Revised: 21 December 2012 - Accepted: 12 January 2013 - Published: 7 February 2013

\begin{abstract}
Dissolved organic carbon (DOC) exports from many catchments in Europe and North-America are steadily increasing. Several studies have sought to explain this observation. As possible causes, a decrease in acid rain or sulfate deposition, concomitant reductions in ionic strength and increasing temperatures were identified. DOC often originates from riparian wetlands; but here, despite higher DOC concentrations, ionic strength in pore waters usually exceeds that in surface waters. In the catchment under study, DOC concentrations were synchronous with dissolved iron concentrations in pore and stream water. This study aims at testing the hypothesis that DOC exports are mediated by iron reduction/oxidation cycles. Following the observed hydrographs, $\delta^{18} \mathrm{O}$ of water and DOC fluorescence, the wetlands were identified as the main source of DOC. Antecedent biogeochemical conditions, i.e., water table levels in the wetlands, influenced the discharge patterns of nitrate, iron and DOC during an event. The correlation of DOC with $\mathrm{pH}$ was positive in pore waters, but negative in surface waters; it was negative for DOC with sulfate in pore waters, but only weak in surface waters. Though, the positive correlation of DOC with iron was universal for pore and surface water. The decline of DOC and iron concentrations in transition from anoxic wetland pore water to oxic stream water suggests a flocculation of DOC with oxidising iron, leading to a drop in $\mathrm{pH}$ in the stream during high DOC fluxes. The pore water did not per se differ in $\mathrm{pH}$. There is, thus, a need to consider processes more thoroughly of DOC mobilisation in wetlands when interpreting DOC exports from catchments. The coupling of DOC with iron fluxes suggested that increased DOC exports could at least, in part, be caused by increasing activities in
\end{abstract}

iron reduction, possibly due to increases in temperature, increasing wetness of riparian wetlands, or by a shift from sulfate dominated to iron reduction dominated biogeochemical regimes.

\section{Introduction}

Dissolved organic carbon (DOC) plays an important role in the acid-base chemistry of surface waters (Driscoll et al., 1994) and contributes significantly to carbon and nutrient cycling in many ecosystems (Billett et al., 2004; McDowell, 2003). Moreover, DOC influences mobility and, thus, fate of metals (Hiraide, 1992) and organic contaminants (Maxin and Kögel-Knabner, 1995), and negatively affects the use of waters as drinking water through the formation of toxic disinfection by-products (Diehl et al., 2000). For many peatlands, DOC also represents a significant contribution to overall carbon fluxes (Limpens et al., 2008). Minding these facts, there has been increasing concern about the observation that DOC concentrations in the discharge of many temperate catchments are rising (Roulet and Moore, 2006; Worrall and Burt, 2007).

A number of studies have been carried out to investigate causes for increased DOC mobilisation and export. Proposed explanations for the observed increase in DOC concentrations in streams and rivers are the observed decrease in acid rain and sulfate deposition, a decrease in ionic strength of surface waters and increasing in temperatures (Clark et al., 2010; Evans et al., 2006; Hruska et al., 2009). Also rewetting of fens during restoration (Glatzel et al., 2003; 


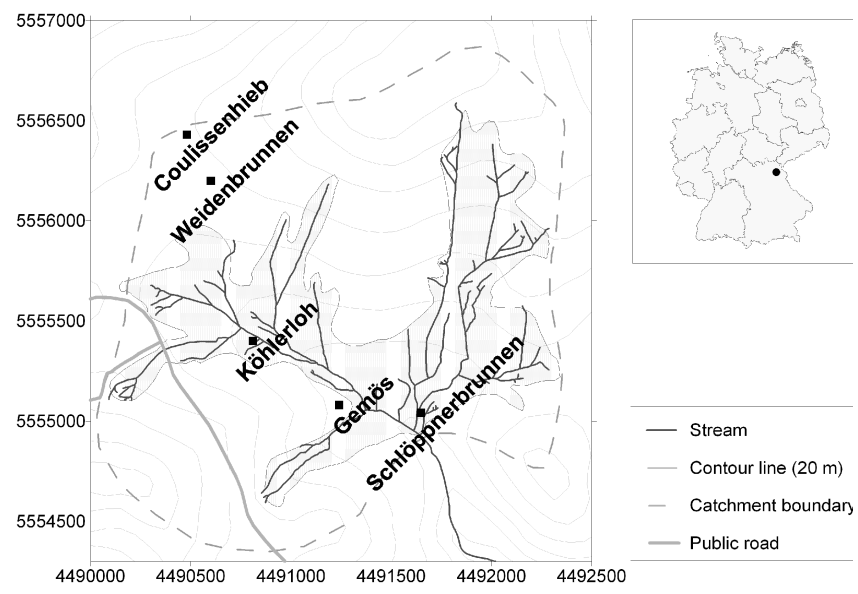

Fig. 1. Overview of the Lehstenbach catchment (Bavaria, Germany) and the location of different sampling sites investigated in this and other studies (e.g., Matzner, 2004). Coulissenhieb and Weidenbrunnen represent upland forested areas, while Köhlerloh, Gemös, and Schlöppnerbrunnen are shallow riparian wetlands. Discharge data was obtained at the catchment outlet near the Schlöppnerbrunnen site, while DOC quality samples were obtained from shallow wells in this and the other wetlands and deep groundwater wells at the forested sites. Reprinted from Schilli et al. (2010) with permission from Elsevier.

Zak and Gelbrecht, 2007) or changes in hydrology and flow paths (Seibert et al., 2009; Köhler et al., 2008) could potentially increase DOC exports.

Regarding the source of DOC, wetlands within a catchment have been identified in playing an important role (Laudon et al., 2011; Austnes et al., 2010). Here, high concentrations of DOC in the pore waters near the surface can be rapidly mobilised and discharged into the adjacent streams during rain events (Bishop et al., 2004; Frei et al., 2010). However, pore water chemistry of mostly anaerobic wetlands significantly differs from surface water in streams (e.g., compare data in Knorr et al., 2009; Hruska et al., 2009). For example, under reducing conditions, high concentrations of DOC occur even in the presence of dissolved ferrous iron in the millimolar range (Blodau et al., 2008). This is also supported by observations of Grybos et al. (2009), who report increasing DOC concentrations up to $8.94 \mathrm{mmol} \mathrm{L}^{-1}$ with increasing $\mathrm{pH}$ under reducing conditions and in the presence of $4.53 \mathrm{mmol} \mathrm{L}^{-1} \mathrm{Fe}^{2+}$. In contrast to observations in surface waters, ionic strength in such reduced waters exceeds, by far, ionic strength of surface waters.

On the process scale, absence of oxygen and, thus, reducing conditions in wetlands lead to the reduction of ferric iron to ferrous iron and sulfate to sulfide; this process is reversible during drought phases, leading to precipitation of ferric iron and reoxidation of reduced sulfur compounds (Knorr et al., 2009). High ionic strength in reduced pore waters dominated by ferrous iron did not seem to have a negative impact on DOC solubility (Blodau et al., 2008; Grybos et al., 2009).
On the other hand, in the transition to oxic conditions, oxidation of reduced iron and sulfur leads to a $\mathrm{pH}$ drop (Knorr et al., 2009; Clark et al., 2005, 2012) and may, thus, initiate flocculation of DOC (Grybos et al., 2009), probably also by ferric iron, which is, besides aluminum, long known as an effective flocculent for organic matter (Lefebvre and Legube, 1993; Libecki and Dziejowski, 2008). In summary, in pore waters one would expect an increase in DOC concentrations to be accompanied by increasing ferrous iron, decreasing sulfate concentrations, and increasing $\mathrm{pH}$ due to reducing conditions. In surface waters, increases in DOC concentrations would also be expected to be accompanied by increasing iron concentrations. On the other hand, oxidation of iron would decrease values of $\mathrm{pH}$ and oxidation of sulfides could increase sulfate concentrations.

The aim of this study was to investigate the dynamics of DOC in the pore waters of riparian wetlands, relate these dynamics to biogeochemical conditions and drivers thereof, and compare these observations to DOC dynamics in the discharge of the adjacent stream. We hypothesised that wet preconditions favour the reductive dissolution of iron and the release of bound DOC into the pore water, while under dry conditions DOC is flocculated and bound by iron(III) phases and, thus, immobilised. This mechanism of DOC mobilisation and immobilisation should translate into a close and positive relationship of iron and DOC in the pore water and in the discharge. In a long term, increases in air temperature, increasing wetness due to climate change, or reduced input of sulfate as electron acceptor could favour iron reduction and, thus, lead to the observed increases in DOC. Moreover, we hypothesised that DOC mobilisation is a priori not controlled by ionic strength or $\mathrm{pH}$, because in anaerobic pore waters of wetlands, ionic strength and $\mathrm{pH}$ may well exceed values observed for aerobic surface water.

\section{Materials and methods}

The study was conducted in the Lehstenbach catchment in Northeastern Bavaria $\left(4.2 \mathrm{~km}^{2}, 695-877 \mathrm{~m}\right.$ elevation, mean annual precipitation $1150 \mathrm{~mm}$, mean annual temperature $5.3^{\circ} \mathrm{C}$; Fig. 1) with about $30 \%$ of the area covered by mostly shallow wetland soils (Gerstberger, 2001; Schilli et al., 2010). As representative wetland sites for the catchment, this study encompassed samples from sites Köhlerloh, Gemös and Schlöppnerbrunnen (wetland groundwater, wetland pore water; Fig. 1). Surface water samples and deep groundwater were sampled at all sites of the catchment, including the forested areas devoid of wetland soils Weidenbrunnen and Coulissenhieb. The catchment is dominated by Norway spruce (Picea abies) with Vaccinium myrtillus, Juncus effusus, Carex nigra, Carex rostrata, Carex canescens, Molinia caerulea, Eriophorum vaginatum, and also Sphagnum mosses in the understory (Matzner, 2004). In the forested upland areas, groundwater tables are mostly 
$>10 \mathrm{~m}$ below surface, while groundwater tables are near the surface in the wetland areas (Lischeid et al., 2002). Details about the wetland and forest soil biogeochemistry have been reported elsewhere (e.g., Knorr et al., 2009; Muhr et al., 2010).

Discharge and surface water chemistry were studied at the catchment outlet near site Schlöppnerbrunnen, using a pressure sensor (Solinst Canada Ltd. Georgetown, ON, Canada) immersed at a discharge flume and weir and an automatic bottle sampler (Teledyne ISCO, Lincoln, NE, USA). Within this study, we obtained discharge chemistry data during several sampling campaigns from August 2010 until September 2011 in $1-4 \mathrm{~h}$ sampling intervals analysed as outlined below. Along with the discharge data, we monitored the groundwater table in $2 \mathrm{~m}$ distance from the stream near the catchment outlet as a reference to relate discharge dynamics and chemistry to hydrological preconditions (pressure transducer as for discharge). Long-term DOC monitoring data was provided for the catchment outlet from 1987 until 2009 by courtesy of the Bavarian Federal Environmental Authority (LFU, Hof, Germany). Detailed pore water chemistry data (from suction samplers; Rhizon ${ }^{\circledR}$, Eijkelkamp, Giesbeck, The Netherlands) was available on a weekly basis for six plots and 6 depths $(5-50 \mathrm{~cm})$ from a former field experiment with natural and manipulatively enforced drying and wetting in 2007 (Knorr et al., 2009) and unpublished DOC data analysed as indicated below. Moreover, pore water and corresponding discharge chemistry data was available on a biweekly basis from April to June 2010 (Knorr, 2010, unpublished). In 2011, 28 shallow wetland groundwater samples (40-100 cm depth from piezometers) and 12 deeper groundwater samples (300-1500 cm depth from monitoring wells) were obtained. In total, more than 260 discharge samples and approximately 1000 pore water samples were included in this study. Air temperature data from 1994-2012 was kindly provided by the Department of Micrometeorology (Prof. T. Foken) at the University of Bayreuth. Long-term data series (DOC, sulfate, and air temperature) were evaluated using LOWESS regression (LOcally WEighted Scatterplot Smoothing) as implemented in MATLAB Version 2011 (MathWorks, Natick, MA, USA). Trend analysis of discharge was done using the Mann-Kendall test with an implemented correction for autocorrelated data (The R project, version 2.15.1; package "zyp", version 0.9-1).

DOC concentrations were measured by thermo-catalytic oxidation on a TOC-VCPN Analyser (Shimadzu, Kyoto, Japan), major anions were analysed with anion chromatography (Metrohm modular IC system IC 752 with chemical suppression, A-Supp 4 column; Metrohm, Herisau, Switzerland). Dissolved iron (after reduction with ascorbic acid) was measured as ferric iron and total iron (after reduction with ascorbic acid) with the phenanthroline assay (Tamura et al., 1974) in pore water samples, and using atomic absorption spectroscopy (PE AAS 4100 XL, Perkin Elmer LAS,
Waltham, MA, USA) for total iron in surface water samples. Values of $\mathrm{pH}$ were measured potentiometrically with a glass electrode (Inlab 412, WTW, Weilheim, Germany). Stable isotope analysis of ${ }^{18} \mathrm{O}$ and ${ }^{2} \mathrm{H}$ in discharge and rainwater was done by thermo-conversion isotope ratio mass spectrometry (TC-IRMS; HTO pyrolysis unit, HEKATech, Wegberg, Germany, coupled to a delta V advantage IRMS via ConFlo IV, Thermo Fisher, Bremen, Germany).

For DOC quality investigations, fluorescence excitationemission matrices (EEMs) were measured on $0.45 \mu \mathrm{m}$ filtered samples, diluted to absorption at $254 \mathrm{~nm}<0.3$ if necessary to minimise inner-filter effects. UV-VIS spectra were recorded on a Varian Cary 1E spectrophotometer (range 200 $800 \mathrm{~nm}, 0.5 \mathrm{~nm}$ resolution; Varian Inc./Agilent Tech., Canta Clara, CA, USA); Fluorescence spectra were recorded on a LS 55 fluorescence spectrometer (excitation range 240 $450 \mathrm{~nm}$ in steps of $5 \mathrm{~nm}$, emission range $300-600 \mathrm{~nm}$ in steps of $0.5 \mathrm{~nm}$; Perkin Elmer, Waltham, MA, USA). Inner filter correction and EEM pretreatment (blank subtraction, Raman normalisation) were performed using the toolbox from Cory and McKnight (2005) and MATLAB Version 2011 (MathWorks, Natick, MA, USA). Samples were reshaped and subjected to a parallel factor analysis (PARAFAC) using toolboxes of Murphy et al. (2010) and of Stedmon and Bro (2008). Following the toolbox of Stedmon and Bro (2008), a 5 component model could be split-half validated and was subsequently used for data interpretation. In total, 160 discharge samples and 40 shallow (wetland) and deep groundwater samples were included in the PARAFAC model.

\section{Results}

\subsection{Long term discharge series}

Regarding the long-term data series of the catchment outlet, mean DOC concentrations in the discharge as estimated by LOWESS regression increased from about $4.7 \mathrm{mg} \mathrm{L}^{-1}$ to $8.6 \mathrm{mg} \mathrm{L}^{-1}$ from 1987 until 2009 (Fig. 2). Also mean annual temperatures increased from $5.6^{\circ} \mathrm{C}$ in 1994 to about $6.7^{\circ} \mathrm{C}$ in 2011 (LOWESS regression, site specific records available from 1994 onwards). On the other hand, mean sulfate concentrations in the discharge declined from about $16 \mathrm{mg} \mathrm{L}^{-1}$ (1987) to about $11 \mathrm{mg} \mathrm{L}^{-1}$ (2009), nitrate declined from 4.1 (1987) to $2.8 \mathrm{mg} \mathrm{L}^{-1}$ (2009), but neither values of $\mathrm{pH}$ nor discharge from the long-term record showed a consistent trend according to the LOWESS regression (for $\mathrm{pH}$, ranging from 4.72 to 4.77 , data not shown) or Mann-Kendall trend analysis (for discharge percentiles and cumulated sum, Fig. 2). Unfortunately, the time series of iron ends in 2001. From 1987 to 2001, iron concentrations in the discharge increased from 0.15 to $0.22 \mathrm{mg} \mathrm{L}^{-1}$. As an estimate for current iron, sulfate, nitrate and DOC exports, we included the median of the 2010-2011 dataset from this study as a red $\mathrm{X}$ in 
Table 1. Ranges in concentrations of DOC, nitrate, sulfate and total iron, and ranges in $\mathrm{pH}$ in the different analysed compartments "wetland pore water", "wetland groundwater", "deep groundwater" and "surface water". Values represent observed minima/medians/means/observed maxima from the available dataset.

\begin{tabular}{|c|c|c|c|c|c|}
\hline Compartment & $\begin{array}{r}\mathrm{DOC} \\
\left(\mathrm{mg} \mathrm{L}^{-1}\right)\end{array}$ & $\begin{array}{r}\mathrm{NO}_{3}^{-} \\
\left(\mathrm{mg} \mathrm{L}^{-1}\right)\end{array}$ & $\begin{array}{c}\mathrm{SO}_{4}^{2-} \\
\left(\mathrm{mg} \mathrm{L}^{-1}\right)\end{array}$ & $\begin{array}{r}\mathrm{Fe}^{\mathrm{tot}} \\
\left(\mathrm{mg} \mathrm{L}^{-1}\right)\end{array}$ & $\mathrm{pH}(-)$ \\
\hline \multirow[t]{3}{*}{ Wetland pore water } & $6.4 / 25.3 /$ & $0.0 / 0.1 / 1.1 /$ & $0.0 / 0.9 / 2.3 /$ & $0.1 / 1.6 / 2.2 / *$ & 2.6/4.8/4.6/ \\
\hline & $31.9 / 150.3$ & 22.0 & 22.1 & 20.4 & 6.1 \\
\hline & $(N=919)^{1}$ & $(N=943)^{1,2}$ & $(N=945)^{3}$ & $(N=858)^{3}$ & $(N=893)^{3}$ \\
\hline \multirow[t]{3}{*}{ Wetland groundwater } & $3.9 / 16.9 /$ & $0.0 / 0.2 / 0.5 /$ & $0.8 / 4.0 / 6.6 /$ & $0.2 / 0.7 / 1.5 /$ & $4.3-6.4^{5}$ \\
\hline & $17.7 / 61.2$ & 4.1 & 36.1 & 5.9 & \\
\hline & $(N=28)^{4}$ & $(N=28)^{4}$ & $(N=28)^{4}$ & $(N=28)^{4}$ & \\
\hline \multirow[t]{3}{*}{ Deep groundwater } & $0.8 / 1.5 / 1.8 /$ & $0.7 / 3.5 / 4.0 /$ & $8.9 / 17.1 / 18.0 /$ & $<\operatorname{LOQ}(0.05)$ & $4.8-5.8^{5}$ \\
\hline & 3.4 & 7.8 & 21.4 & $\max .0 .24$ & \\
\hline & $(N=12)^{4}$ & $(N=12)^{4}$ & $(N=12)^{4}$ & $(N=12)^{4}$ & \\
\hline \multirow[t]{6}{*}{ Surface water } & $2.8 / 8.1 / 10.9 /$ & $1.1 / 3.1 / 2.9 /$ & $0.4 / 11.3 /$ & $0.0 / 0.3 / 0.4 /$ & $3.9 / 4.5 / 4.6 /$ \\
\hline & 33.7 & 5.4 & $11.2 / 41.0$ & 1.5 & 5.9 \\
\hline & $(N=547)^{4}$ & $(N=534)^{4}$ & $(N=536)^{4}$ & $(N=474)^{4}$ & $(N=155)^{6}$ \\
\hline & $1.3 / 5.7 / 7.3 /$ & $0.5 / 3.7 / 3.8 /$ & $6.9 / 13.0 / 14.1 /$ & & \\
\hline & 34.0 & 9.3 & 34.5 & & \\
\hline & $(N=536)^{7}$ & $(N=544)^{7}$ & $(N=544)^{7}$ & & \\
\hline
\end{tabular}

${ }^{1}$ Knorr (2007) (unpublished); ${ }^{2}$ Goldberg et al. (2010); ${ }^{3}$ Knorr et al. (2009); ${ }^{4}$ this study; ${ }^{5}$ range from Lischeid (2005) (unpublished); ${ }^{6}$ Knorr (2010) (unpublished); ${ }^{7}$ Long-term record 1987-2009, Bavarian Federal Environmental Authority 2010 (unpublished); * $\mathrm{Fe}^{2+}$ only.

Fig. 2. This rough estimate would suggest a stabilisation of sulfate, nitrate and DOC exports in the last years and an increase of iron exports from 2001 until today, parallel to DOC.

\subsection{Concentration levels and correlations in surface, ground-, and pore water}

Based on the observed concentrations, highest DOC concentrations occurred in the pore water of the upper $50 \mathrm{~cm}$ of the wetland soils (about $6-150 \mathrm{mg} \mathrm{L}^{-1}$ ), while concentrations in the deeper groundwater were mostly below $2-3 \mathrm{mg} \mathrm{L}^{-1}$. Nitrate was mostly absent in wetland pore waters, except of few and short-lived occasions during dry weather conditions (see also Goldberg et al., 2010), while concentrations in the deeper groundwater were between 3 and $8 \mathrm{mg} \mathrm{L}^{-1}$. Sulfate concentrations in the wetland pore waters were variable, depending on weather conditions and groundwater table, ranging from $<0.05 \mathrm{mg} \mathrm{L}^{-1}$ to $20 \mathrm{mg} \mathrm{L}^{-1}$. In the deeper groundwater, sulfate ranged from $10-21 \mathrm{mg} \mathrm{L}^{-1}$. An overview of ranges in concentrations of DOC, nitrate, sulfate and total iron and ranges in $\mathrm{pH}$ is given in Table 1 . Aluminum concentrations in pore and surface water (not given in the Table) ranged from $7-14 \mathrm{mg} \mathrm{L}^{-1}$ and $0.4-1.0 \mathrm{mg} \mathrm{L}^{-1}$, respectively. Using two different observations of solute concentrations of either high or low ionic strength, considering also other dissolved metals, chloride and bicarbonate (data not shown), we obtained two upper and lower ionic strength estimates for pore and surface water. For the wetland pore water, ionic strength spanned from about 2.90 to $6.80 \mathrm{mmol} \mathrm{L}^{-1}$ at a $\mathrm{pH}$ of 3.5 to 6 , and dominated by $\mathrm{Fe}^{2+}, \mathrm{Al}^{3+}$, and nega- tive charge from dissociated organic acids as estimated from charge balance considerations (Hruška et al., 2001). In the surface water (discharge samples), ionic strength was notably lower and ranged from 0.53 to $1.04 \mathrm{mmol} \mathrm{L}^{-1}$ at a comparable $\mathrm{pH}$ range of 3.8 to 6 , but dominated by $\mathrm{Ca}^{2+}, \mathrm{Al}^{3+}$, $\mathrm{SO}_{4}^{2-}$, and negative charge from dissociated organic acids.

Within the surface water samples from this study, we found a positive correlation of DOC and iron concentrations with discharge. For nitrate and $\mathrm{pH}$ there was, in general, a negative correlation with discharge. At comparably high discharge events and during snow melt high nitrate concentrations coincided with high discharges (not shown), yielding a lower correlation coefficient reported in Table 2. Sulfate was not significantly correlated to discharge, as concentrations depended strongly on preconditions (dry, wet). However, a closer inspection revealed a slight, negative correlation of sulfate with discharge in summer, a slight, positive correlation in winter. No correlations with discharge were calculated for the long-term data, as the time point of sampling could only be correlated with an average discharge for the sampling day, which obscures the hourly dynamics of discharge chemistry (Table 3). Regarding the correlations among solutes in the surface water samples, DOC was most strongly and positively correlated with dissolved iron, while being negatively correlated with $\mathrm{pH}$ and nitrate, albeit weaker (Table 2). No significant correlation was found for DOC and sulfate. While most correlations of the long-term data (Table 3) agree with the data obtained in this study, some pairs yielded opposite dependencies. While $\mathrm{pH}$ correlated positively with nitrate and sulfate in this study, $\mathrm{pH}$ was negatively correlated 

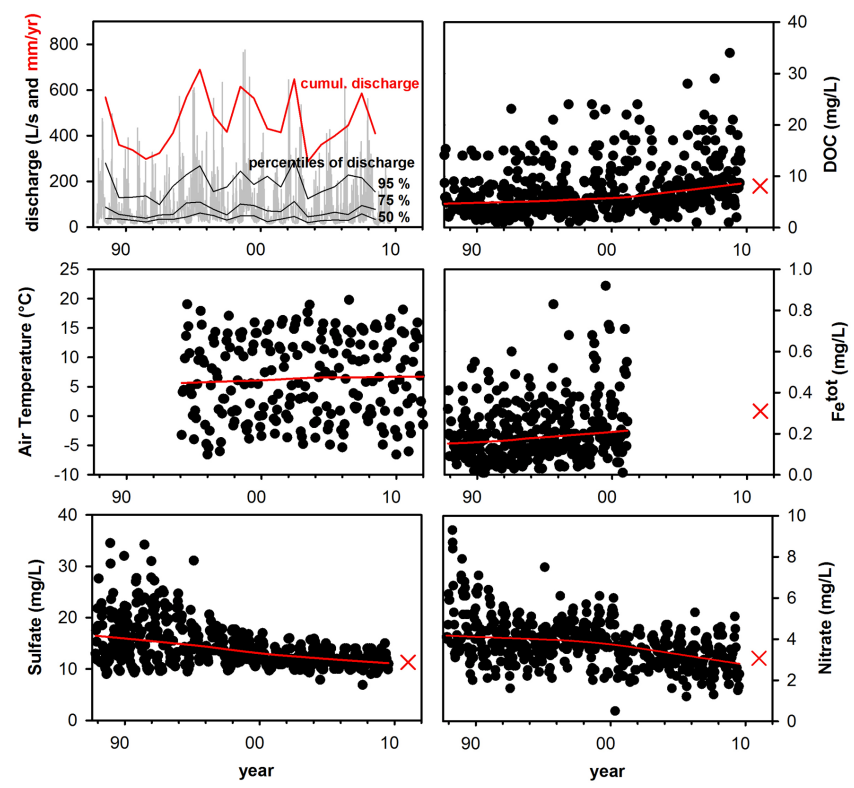

Fig. 2. Discharge, DOC concentrations, air temperature, total iron $\left(\mathrm{Fe}^{\mathrm{tot}}\right)$, sulfate and nitrate concentrations at the catchment outlet (near "Schlöppnerbrunnen"). Temperature data was recorded at the site "Coulissenhieb" and provided by the Department of Micrometeorology (Prof. Foken, University of Bayreuth). Solute chemistry (filled dots) is from the long-term record of the Bavarian Federal Environmental Authority (unpublished). The red line trend was derived by LOWESS regression; the thin X marks the median of the one year measurement campaign results of this study as a rough estimate for the current trend. The time scale is similar in all graphs (1 August 1987-1 January 2011) to facilitate comparison, although not all data was available for the displayed period. Increase of Temperature from LOWESS: $5.63^{\circ} \mathrm{C}$ (1994) to $6.75^{\circ} \mathrm{C}$ (2012), DOC (LOWESS): 4.68 (1987) to $8.57 \mathrm{mg} \mathrm{L}^{-1}$ (2009), iron: 0.15 (1987, LOWESS) to $0.30 \mathrm{mg} \mathrm{L}-1$ (Median 2010-2011, see Table 1); decrease of sulfate (LOWESS): 16.48 (1987) to $11.14 \mathrm{mg} \mathrm{L}^{-1}$ (2009), nitrate (LOWESS): $4.17 \mathrm{mg} \mathrm{L}^{-1}$ (1987) to $2.80 \mathrm{mg} \mathrm{L}^{-1}$ (2009). No significant trends in the percentiles of discharge or in cumulated discharge (Mann-Kendall, sigma $>0.18$ ).

to nitrate and sulfate in the long-term dataset. Also the correlation of iron with sulfate was reversed.

In the pore water samples, DOC was again most strongly and again positively correlated with dissolved iron, but in contrast to the surface water samples also positively correlated with values of $\mathrm{pH}$. Nitrate was similarly, albeit weaker correlated with DOC in a negative manner; for sulfate also a slight negative correlation with DOC was observed, contrarily to surface water samples from 2010-2011 of this study (Table 4).

\subsection{Discharge dynamics of DOC, nitrate and event water contribution}

For the identification of flow components, their possible respective source areas and antecedent biogeochemical condi- tions, two discharge events of similar magnitude (peak discharge 0.11 to $0.12 \mathrm{~m}^{3} \mathrm{~s}^{-1}$ ), but different preconditions in terms of groundwater table were chosen (Fig. 3). Under wet preconditions (20 July 2011, $23 \mathrm{~mm}$ of rainfall, groundwater table $19 \mathrm{~cm}$ below surface at the reference monitoring well), DOC concentrations increased with discharge as usually observed, although the maximum of DOC concentrations was delayed by about 240 min compared to the maximum in discharge. Under dry preconditions (31 May 2011, $41 \mathrm{~mm}$ of rainfall, groundwater table $62 \mathrm{~cm}$ below surface at the reference monitoring well), DOC concentrations increased similarly with discharge, with a delay of the DOC maximum about $150 \mathrm{~min}$ compared to discharge. According to a translation of the discharge-time relationship into a discharge-concentration plot (as e.g., proposed in Evans and Davies, 1998), DOC followed under both conditions a counter-clockwise hysteresis loop, indicating a fast flow component poorer in DOC at the begin of the discharge event, followed by high DOC concentrations delivered by an intermediate flow component. Finally, DOC concentrations declined, lagging behind the decline in discharge, indicative of a slow flow component rich in DOC, until base flow poor in DOC was reached again. For nitrate, the two different preconditions translated into two different dischargeconcentration patterns. Under wet preconditions, nitrate concentrations in the stream are diluted by a fast flow component and subsequent intermediate flow component, until recovering to pre-event values when approaching base flow conditions. Under dry preconditions, nitrate concentrations first increased ("nitrate flush"), following a clockwise hysteresis and indicative of a fast flow component rich in nitrate that is related to antecedent biogeochemical conditions. Thereafter, nitrate concentrations were slowly declining back to pre-event values when approaching base flow. Summarised, DOC seemed to be mainly released from an intermediate flow component in terms of time scales, irrespective of preconditions, while the fast flow component at the begin of the discharge event contained somewhat less DOC and was either free of nitrate (wet preconditions), or had higher concentrations of nitrate compared to the other flow components (dry preconditions).

Regarding the contribution of rain event water to discharge, the maximum of event water contribution was under both wet and dry preconditions shortly before the maximum of the discharge (1-2h, Fig. 3). In case of the dry preconditions, this maximum apparently coincided with the initial flush of nitrate rich water. Irrespective of the preconditions, the decline of the event water coincided with the retarded decline in DOC concentrations (Fig. 3). In summary, the isotope data of the discharging waters also suggested some surface near fast flow component induced by rain event water, as derived from solute data. The slow decline of event water contribution towards the end of the discharge event suggested a shallow and intermediate flow component susceptible for dilution with rainwater. Nevertheless, also a modelled base 

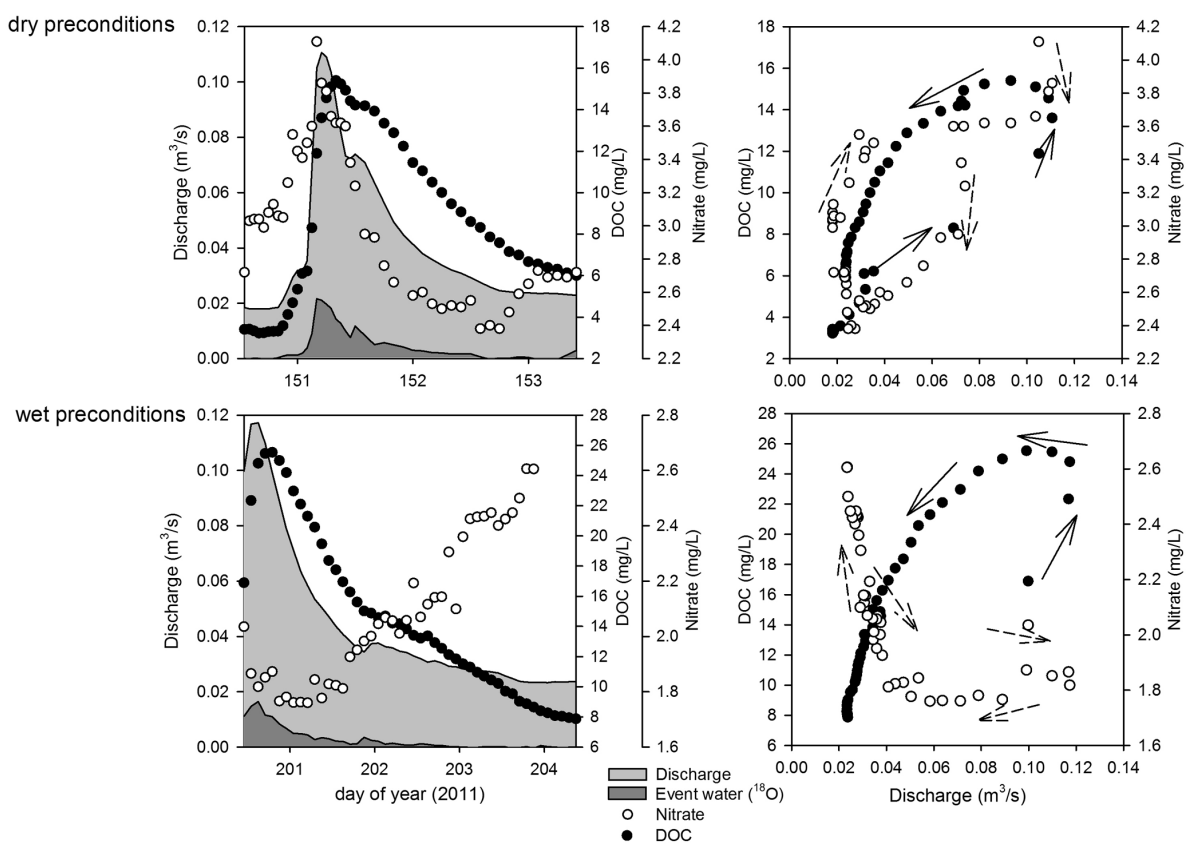

Fig. 3. Hydrographs (light gray) and concentrations of DOC and nitrate for the two selected discharge events under dry antecedent conditions (groundwater table $62 \mathrm{~cm}$ below surface at reference well, 31 May 2011, $41 \mathrm{~mm}$ of rainfall) and wet preconditions (groundwater table $19 \mathrm{~cm}$ below surface at reference well, 20 July 2011, $23 \mathrm{~mm}$ of rainfall). Contributions of event water as estimated from a two component mixing model of $\delta^{18} \mathrm{O}$ from rainwater and pre-event base flow are depicted in dark gray. Note that the initial nitrate peak under dry preconditions coincided with the maximum in event water distribution, while under wet preconditions there was no nitrate flushing and the concentration minimum coincided with the DOC maximum. Furthermore, under dry preconditions concentrations of DOC remained lower, despite a comparable contribution of event water. Corresponding graphs on the right represent the same events as concentration vs. discharge plots (CQ-plots) to identify the discharge patterns of the respective source terms (Evans and Davies, 1998). Dashed arrows mark the C-Q hysteresis of nitrate (open circles), solid arrows indicate the pattern for DOC (solid dots).

Table 2. Correlations (Pearson) in surface water between discharge, solutes and groundwater level (GW, in $\mathrm{m}$ below surface). Data for Q, DOC, nitrate, sulfate and iron: this study; data for $\mathrm{pH}$ from Knorr (2010) (unpublished).

\begin{tabular}{|c|c|c|c|c|c|c|c|}
\hline & $\begin{array}{r}\mathrm{Q} \\
\left(\mathrm{m}^{3} \mathrm{~s}^{-1}\right)\end{array}$ & $\begin{array}{r}\text { DOC } \\
\left(\mathrm{mg} \mathrm{L}^{-1}\right)\end{array}$ & $\begin{array}{r}\mathrm{NO}_{3}^{-} \\
\left(\mathrm{mg} \mathrm{L}^{-1}\right)\end{array}$ & $\begin{array}{c}\mathrm{SO}_{4}^{2-} \\
\left(\mathrm{mg} \mathrm{L}^{-1}\right)\end{array}$ & $\begin{array}{r}\mathrm{Fe}^{\mathrm{tot}} \\
\left(\mathrm{mg} \mathrm{L}^{-1}\right)\end{array}$ & $\mathrm{pH}(-)$ & $\begin{array}{r}\text { GW level } \\
(\mathrm{m})\end{array}$ \\
\hline $\mathrm{Q}\left(\mathrm{m}^{3} \mathrm{~s}^{-1}\right)$ & - & $0.756 * *$ & $-0.297 * *$ & -0.052 & $0.450 * *$ & No data & $-0.452 * *$ \\
\hline $\operatorname{DOC}\left(\mathrm{mg} \mathrm{L}^{-1}\right)$ & $N=547$ & - & $-0.673 * *$ & $-0.230 * *$ & $0.954 * *$ & $-0.498 * *$ & $-0.514 * *$ \\
\hline $\mathrm{NO}_{3}^{-}\left(\mathrm{mg} \mathrm{L}^{-1}\right)$ & $N=534$ & $N=534$ & - & $0.344 * *$ & $-0.586 * *$ & $0.448 * *$ & $0.157 * *$ \\
\hline $\mathrm{SO}_{4}^{2-}\left(\mathrm{mg} \mathrm{L}^{-1}\right)$ & $N=536$ & $N=536$ & $N=534$ & - & $-0.310 * *$ & $0.444 * *$ & 0.025 \\
\hline $\mathrm{Fe}^{t o t}\left(\mathrm{mg} \mathrm{L}^{-1}\right)$ & $N=474$ & $N=474$ & $N=466$ & $N=468$ & - & $-0.481 * *$ & $-0.459 * *$ \\
\hline $\mathrm{pH}(-)$ & No data & $N=157$ & $N=157$ & $N=157$ & $N=140$ & - & No data \\
\hline GW level (m) & $N=547$ & $N=547$ & $N=534$ & $N=536$ & $N=474$ & No data & - \\
\hline
\end{tabular}

Levels of significance: $* p<0.1, * * p<0.05$, no asterisk: not significant.

flow for both events declined in a way paralleling the decline in DOC (not shown).

\subsection{DOC quality parameters from fluorescence spec- troscopy and PARAFAC modeling}

Using a set of 200 DOC samples from deep groundwater, shallow wetland groundwater and discharge, a 5 fluores- cence component model could be obtained and split-half validated following the toolbox and suggestions of Stedmon and Bro (2008). Of these hypothetical fluorophores, fluorescent components number 1, 2 and 3 had higher contributions in samples obtained from wetlands (shallow wetland groundwater) (Fig. 4). Fluorescent component 5 contributed more to total fluorescence in deep groundwater samples, while component 4 did not differ between the sampled DOC sources. 

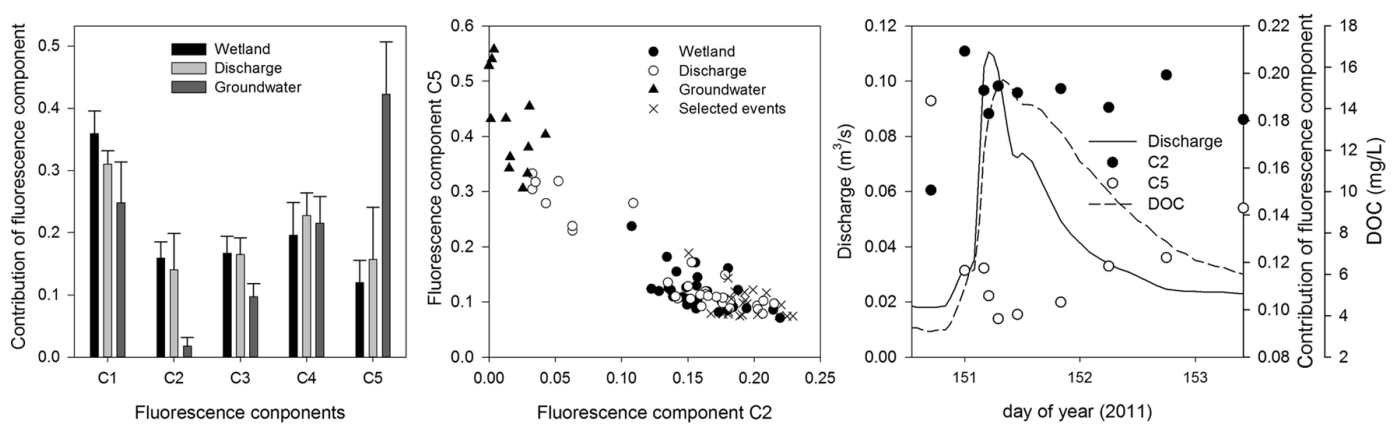

Fig. 4. Left: contributions of the 5 identified fluorescence components (PARAFAC Model after Stedmon and Bro, 2008) to the samples from the compartments "shallow wetland groundwater" (Wetlands) and "deep groundwater" (Groundwater) and in the stream water (Discharge). Middle: meparation of the DOC sources by use of the two fluorescence components C2 (characterising wetland DOC quality) and C5 (characterising groundwater DOC quality). Those of the discharge samples (open circles) resembling groundwater samples (solid triangles) were all sampled upstream close to a groundwater seepage area with little impact by wetland soils. Samples from the two selected discharge events (see results section) are depicted as X. Right: contribution of fluorescence components C2 and C5 to total DOC fluorescence during the discharge event from 31 May 2011 (dry preconditions), discharge hydrograph, and DOC concentrations over time.

DOC samples from discharge were either quite similar to the wetland samples (components 2, 3,5) or lined up between deep groundwater and wetland groundwater quality indices (component 1). From these observations, components 1, 2 and 3 may be termed to be indicative of wetland-borne DOC, component 5 indicative of deep groundwater-borne DOC. Using a plot of component 2 (wetland-borne) versus component 5 (deep groundwater-borne), the similarity of DOC in discharge to the quality of DOC from wetlands was obvious (Fig 4). Only few DOC samples in discharge that had been sampled close to an area with exfiltrating deep groundwater and little influence of soils (site "Weidenbrunnen", Fig. 1) or that had been sampled during base-flow conditions lined up along a mixing line of components 2 and 5. As depicted exemplarily in Fig. 3, the fluorescence component assigned to deep groundwater declined during discharge events and recovered to the pre-event level when approaching base-flow conditions again, while the component assigned to wetland DOC increases and remains high.

\subsection{DOC dynamics in the pore waters of the riparian wetlands}

DOC concentrations in the pore water were closely related to the release of ferrous iron into the pore water, thus, mirroring the dynamics of iron reduction and oxidation. This is exemplarily shown for 4 experimental plots in the Schlöppnerbrunnen wetland of catchment under study (Fig. 5) that has been described previously (Knorr et al., 2009). During phases of high water tables, iron reduction was favoured and led to concomitant DOC release, during phases of lower water tables DOC concentrations declined again. This translated into the described high correlation of dissolved iron and DOC in the porewater in Table 4. Regarding the dynamics of sulfate, the observed concentration pattern was inverse compared to DOC, as during reducing conditions not only iron was reduced and released into the porewater, but also sulfate reduction initiated and led to depletion of sulfate. Generally and as expected, values of $\mathrm{pH}$ increased during phases of reducing conditions, while decreasing during phases of oxidation (not shown, Knorr et al., 2009). Especially in the middle of the growing season (about 160-220 days) reducing conditions and associated DOC release were also observed very close to the soil surface above the water table. Although differing in the absolute concentrations and partly also in response times upon wetting and drying, the parallel dynamics of dissolved iron and DOC and the opposite dynamics of sulfate and DOC was obvious for all plots under study.

\subsection{Indicators in the surface water for redox induced DOC mobilisation}

While nitrate was negatively correlated with DOC in pore and surface water (Tables 2-4, Fig. 6), high nitrate concentrations in the discharge also only occurred at low groundwater tables, i.e., under oxidised preconditions, or during initial nitrate flushing events after drought phases (Fig. 6). For iron, the opposite trend was observed, with high iron concentrations - along with high DOC concentrations - at high groundwater tables, i.e., reducing preconditions. For sulfate there was an obvious difference between seasons. While the correlation with DOC was, in general, weakly negative (see above), lower sulfate concentrations at high DOC concentrations were mainly observed during the summer months at high water tables (reducing conditions). In winter, a weakly positive correlation with DOC was observed, despite high groundwater table levels. 
Table 3. Correlations (Pearson) among solutes in long-term data 1987-2009 (Bavarian Federal Environmental Authority, 2010, unpublished).

\begin{tabular}{lrrrrr}
\hline & $\begin{array}{r}\mathrm{DOC} \\
\left(\mathrm{mg} \mathrm{L}^{-1}\right)\end{array}$ & $\begin{array}{r}\mathrm{NO}_{3}^{-} \\
\left(\mathrm{mg} \mathrm{L}^{-1}\right)\end{array}$ & $\begin{array}{r}\mathrm{SO}_{4}^{2-} \\
\left(\mathrm{mg} \mathrm{L}^{-1}\right)\end{array}$ & $\begin{array}{r}\mathrm{Fe}^{\mathrm{tot}} \\
\left(\mathrm{mg} \mathrm{L}^{-1}\right)\end{array}$ & $\mathrm{pH}(-)$ \\
\hline $\mathrm{DOC}\left(\mathrm{mg} \mathrm{L}^{-1}\right)$ & - & $-0.376^{* *}$ & $0.120^{* *}$ & $0.762^{* *}$ & $-0.583^{* *}$ \\
$\mathrm{NO}_{3}^{-}\left(\mathrm{mg} \mathrm{L}^{-1}\right)$ & $N=521$ & - & $0.467 * *$ & $-0.273^{* *}$ & $-0.219^{* *}$ \\
$\mathrm{SO}_{4}^{2-}\left(\mathrm{mg} \mathrm{L}^{-1}\right)$ & $N=521$ & $N=533$ & - & $0.281^{* *}$ & $-0.646^{* *}$ \\
$\mathrm{Fe}^{\mathrm{tot}}\left(\mathrm{mg} \mathrm{L}^{-1}\right)$ & $N=330$ & $N=337$ & $N=337$ & - & $-0.525^{* *}$ \\
$\mathrm{pH}(-)$ & $N=526$ & $N=533$ & $N=533$ & $N=341$ & - \\
\hline
\end{tabular}

Levels of significance: $* * p<0.05$.

\section{Discussion}

The aim of this study was to find support for the hypothesis that the long-term increase in DOC exports from catchments is not only due to a decline in sulfate or acid rain deposition or due to a decrease in ionic strength (Clark et al., 2010; Hruska et al., 2009), but also by changes in biogeochemical processes and DOC mobilisation processes and hydrological flow paths in the source areas (e.g., Haaland et al., 2010; Clark et al., 2012). Many studies have so far investigated DOC exports from catchments and the controls thereof (Clark et al., 2010), but fewer studies are available investigating the DOC source areas and the DOC in runoff in a complementary approach (Worrall et al., 2008; Clark et al., 2008, 2012). If data from wetlands as DOC source areas are available, often no redox sensitive probing of predominant pore water species had been achieved, especially in monitoring programmes (Clark et al., 2005; Worrall and Burt, 2007). Observations of DOC solubility and interaction with, e.g., iron in surface waters may differ due to prevailing oxic conditions (McKnight et al., 1992) and not accounting for redox induced changes in solutes and $\mathrm{pH}$ during the transition from anoxic to oxic conditions (Peiffer et al., 1999; Knorr et al., 2009). In this study, redox sensitive pore water data monitored over one growing season (Knorr et al., 2009) and additional DOC concentrations were compared to a long-term record of discharge chemistry (1987-2009) and several short-term investigations of high temporal resolution. This approach yields several new insights in DOC production and mobilisation in pore waters, the response of DOC in pore water to drought effects, the transition of DOC from the source areas into the stream, and the impact of differing hydrological preconditions (dry - wet) on the respective DOC and solute outputs.

It was beyond the scope of the study to elaborate on statistical models to predict DOC in stream waters and to elucidate controls of DOC release based on advanced statistical tools. The focus of this study was in finding a link between processes in the riparian peatlands and the observed stream water chemistry, and to relate this process-based understanding to an alternative hypothesis to explain increased DOC concentrations in the discharge of catchments with a significant proportion of peat soils. Therefore, correlations of solutes,
Table 4. Correlations (Pearson) between solutes in pore water. Data for nitrate, sulfate, iron and $\mathrm{pH}$ from Knorr et al. (2009), DOC data from Knorr (2007) (unpublished).

\begin{tabular}{lrrrrr}
\hline & $\begin{array}{r}\mathrm{DOC} \\
\left(\mathrm{mg} \mathrm{L}^{-1}\right)\end{array}$ & $\begin{array}{r}\mathrm{NO}_{3}^{-} \\
\left(\mathrm{m} \mathrm{L}^{-1}\right)\end{array}$ & $\begin{array}{r}\mathrm{SO}_{4}^{2-} \\
\left(\mathrm{mg} \mathrm{L}^{-1}\right)\end{array}$ & $\begin{array}{r}\mathrm{Fe}^{2+} \\
\left(\mathrm{mg} \mathrm{L}^{-1}\right)\end{array}$ & $\mathrm{pH}(-)$ \\
\hline $\mathrm{DOC}\left(\mathrm{mg} \mathrm{L}^{-1}\right)$ & - & $-0.110^{* *}$ & $-0.441^{* *}$ & $0.776^{* *}$ & $0.405^{* *}$ \\
$\mathrm{NO}_{3}^{-}\left(\mathrm{mg} \mathrm{L}^{-1}\right)$ & $N=650$ & - & $0.174 * *$ & $-0.095^{*}$ & $-0.134 * *$ \\
$\mathrm{SO}_{4}^{2-}\left(\mathrm{mg} \mathrm{L}^{-1}\right)$ & $N=651$ & $N=679$ & - & $-0.395^{* *}$ & $-0.538^{* *}$ \\
$\mathrm{Fe}^{2+}\left(\mathrm{mg} \mathrm{L}^{-1}\right)$ & $N=615$ & $N=638$ & $N=640$ & - & $0.303 * *$ \\
$\mathrm{pH}(-)$ & $N=654$ & $N=679$ & $N=680$ & $N=642$ & - \\
\hline
\end{tabular}

Levels of significance: $* p<0.1, * * p<0.05$, no asterisk: not significant.

discharge, groundwater levels and $\mathrm{pH}$ were calculated for linear relationships only, which may be seen as a limitation of this study, but should not affect the overall argumentation.

As presented in Fig. 2, the observed long-term increase of DOC concentrations at the catchment outlet was paralleled by an increase in temperature, a decline in sulfate and nitrate, no clear change in $\mathrm{pH}$ or discharge, but a remarkable increase of dissolved iron. It was also reported that increases in DOC concentrations have often, but not exclusively been observed for catchments with a relatively high proportion of peat soil coverage (Worrall and Burt, 2007; Billett et al., 2006) which is also the case in the catchment under study here (about $30 \%$ ). These observations are, therefore, quite similar to what has been reported from other catchments with increasing DOC concentrations and similar deposition histories (Evans et al., 2006; Monteith et al., 2007). In many studies on DOC, there is little information available for iron in the discharge. While Kritzberg and Ekström (2012) did observe parallel increases of iron and DOC, they hypothesised that DOC and iron do not necessarily have identical mobilisation processes, as the ratios of iron and DOC varied among catchments. Interestingly, in the catchment under study here, iron to DOC ratios did not change significantly since 1987 (not shown), indicating a parallel dynamics.

Nevertheless, also increased temperatures, as observed here, have already been identified to contribute to increased DOC exports (Evans et al., 2006; Worrall et al., 2004; Winterdahl et al., 2011). No significant trends in discharge could be identified, verifying results of Lischeid (2001a). Thus, in the catchment under study here, changes in hydrology as a cause for increased DOC concentrations, as proposed by other studies (Haaland et al., 2010; Köhler et al., 2008), are not very likely.

\subsection{Source identification for DOC to assign relevant processes}

Regarding the pore water data compared to the stream water chemistry, highest DOC concentrations occurred in the wetland pore and ground water, lowest concentrations in the deep groundwater and intermediate concentrations in the discharge. Thus, based on the observed concentration ranges, 

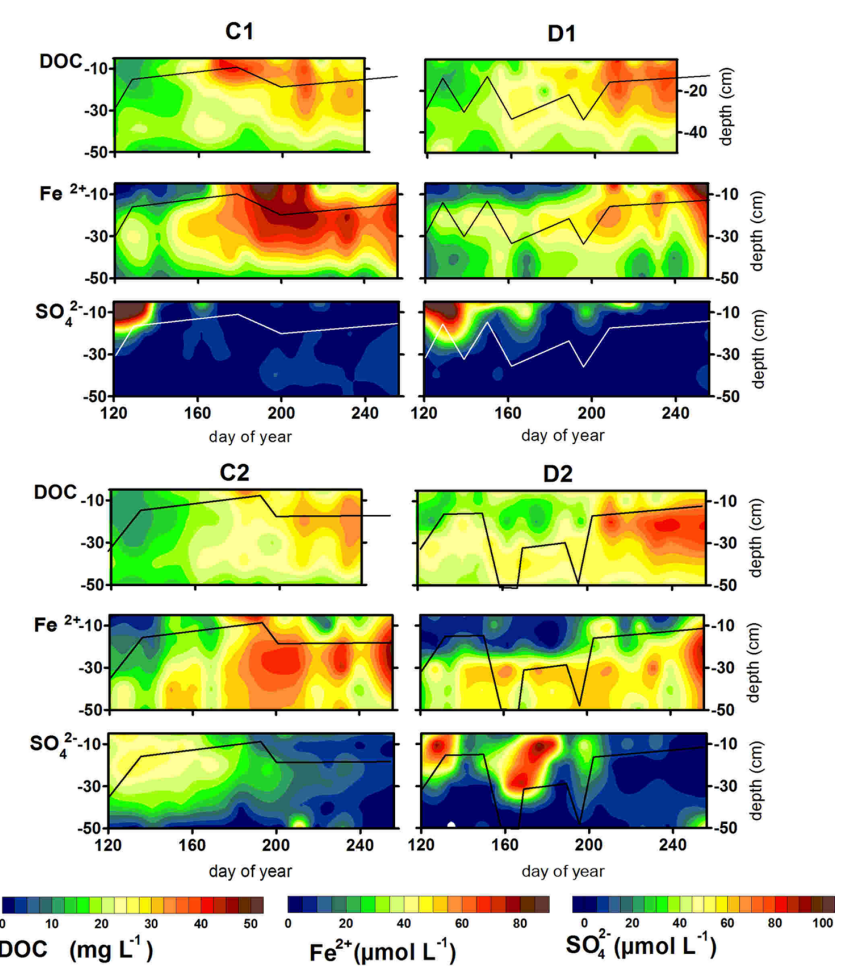

Fig. 5. Porewater DOC, $\mathrm{Fe}^{2+}$ and $\mathrm{SO}_{4}^{2-}$ concentration dynamics (colour scale) during water table fluctuations in 4 experimental plots in the Schlöppnerbrunnen Fen in the Lehstenbach catchment over depth (y-axis) and time (x-axis). Experimental details of the in situ water table manipulation experiments carried out at this site and details about the biogeochemical processes in the plots have been reported elsewhere (Knorr et al., 2009). The colour scale of the solutes applies to all 4 plots C1, C2, D1 and D2; the thin solid line represents the approximate water table level in the respective experimental plots. Due to measurement problems, the DOC time series ended earlier compared to the $\mathrm{Fe}^{2+}$ and $\mathrm{SO}_{4}^{2-}$ time series in plots $\mathrm{C} 1, \mathrm{D} 1$ and $\mathrm{C} 2$; therefore, the size of the graphs has been adjusted to a similar x-axis scaling. Graphs were interpolated from weekly samplings ( 7 days) over 6 depths $(5,10,20,30,40$, and $50 \mathrm{~cm})$ with an inverse distance weight approach, as implemented in Surfer Version 8 (Golden Software, Golden CO, USA).

the source of DOC must have been the wetlands, a finding which was supported by our DOC quality investigations (Fig. 4) and could be expected based on previous studies (Austnes et al., 2010; Laudon et al., 2011; Morel et al., 2009). An increase of DOC concentrations was always paralleled by an increase of DOC quality parameters assigned to the wetlands as source areas, while quality indices indicative of groundwater-borne DOC declined. This suitability of PARAFAC modelling of fluorescence components of DOC has already been demonstrated previously (Fellman et al., 2009; Inamdar et al., 2012). Interestingly, the hypothetical fluorophore indicative of groundwater (component 5) resembled a protein-like fluorescence, as also observed by Inamdar et al. (2012), while DOC from wetlands had more humic-like fluorescence indicative of refractory organic matter. The wetlands represented not only sources of DOC, and iron, though, but also of acidity, as $\mathrm{pH}$ decreased with increasing DOC concentrations originating from the wetlands. This acidity may of course be related to reoxidation of reduced species, such as sulfides and ferrous iron (Knorr et al., 2009; Clark et al., 2012). Sulfate stemmed mostly from deep groundwater, as deep groundwater has longer residence times and, therefore, still contains high sulfate loads from the past high deposition (Lischeid, 2001b). For nitrate, the predominant source was probably also deeper groundwater, however, after longer drought phases followed by strong rain events, nitrate was initially flushed out from a fast flow component, which could also be attributed to the shallow surface layers of wetlands. Although there is little data available about nitrate in wetlands, this is reasonable, regarding the earlier study of Goldberg et al. (2010), who reported the occurrence of peaks of nitrate in surface near pore waters in the wetland Schlöppnerbrunnen (see Fig. 1) under dry conditions.

The source attribution of DOC was further supported by a more detailed analysis of the hydrographs. DOC concentrations in a concentration-over-discharge plot (C-Q plot) always followed a counter clockwise hysteresis loop, irrespective of the preconditions (Fig. 3). This suggested a surface near fast flow component, as in the upper layers of the riparian wetland soils (Bishop et al., 2004) and in the hummock/hollow structures (Frei et al., 2010) hydraulic conductivities increase and allow for a fast response towards rain events. Thus, also the contribution of rain event water based on $\delta^{18} \mathrm{O}$ data peaked during this initial rise in discharge (Fig. 3), while the increase of DOC concentration lagged behind due to lower DOC concentrations in the oxic upper wetland layers and a slower response of less shallow pore waters rich in DOC (Figs. 2, 4). Under dry preconditions, an initial nitrate flush at the beginning of a discharge event occurred, as could be explained by the occasionally elevated nitrate concentrations in the aerated surface layers of the wetlands. Under wet preconditions, no nitrate could be detected in the surface near wetland pore water (Goldberg et al., 2010), thus, no initial nitrate flush occurred. This was supported by the observation that high nitrate concentrations in the discharge always coincided with low groundwater table levels (Fig. 5), except if there was an initial nitrate flushing effect, when groundwater tables quickly rose after drought phases and nitrate concentrations were still high. As the high DOC concentrations originated from pore waters below 5$10 \mathrm{~cm}$ (Fig. 4) and these depths are probably less affected by surficial rainfall, the DOC dynamics during discharge remained similar, irrespective of the preconditions and during peaks of DOC, the contribution of event water already declined. This particular discharge pattern may not be universal, as, e.g., McGlynn and McDonnel (2003) observed a clockwise hysteresis for DOC, i.e., DOC concentrations rising faster than discharge, but the authors also claimed the importance of connecting observed hydrological dynamics 

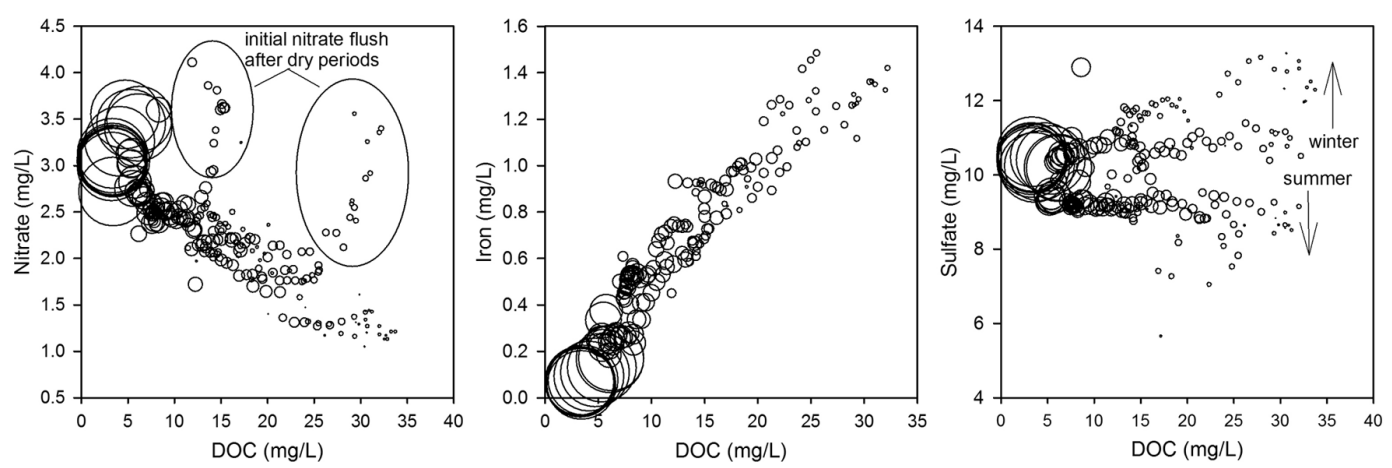

Fig. 6. Plots of DOC concentrations versus nitrate, iron and sulfate from the one year dataset of this study. The size of the open circles represents the depth of the groundwater table at the specific point of time, with largest circles meaning a groundwater table depth of $62 \mathrm{~cm}$ below surface and smallest dots a groundwater table depths of $2 \mathrm{~cm}$ below surface at the reference well. Note that deviations from the linear relationship of DOC with nitrate occurred at high rainfall after dry conditions, causing an initial nitrate flush (see Fig. 2, upper graphs). For sulfate, the correlation tended to be negative in summer (presumably due to reductive elimination in wetlands), while positive in winter (less reducing activity in wetlands and more surface flow).

in the discharge to the biogeochemical conditions and hydrological dynamics of the particular source areas, as e.g., implemented by a model approach of Seibert et al. (2009). The observed pattern in DOC, nitrate and iron concentrations in the discharge, therefore, further support the importance of hydrological and, thus, biogeochemical redox preconditions in the wetlands for solute exports.

\subsection{Processes at the wetland-stream interface}

An important point is that there was a strong decline in concentration levels of DOC during the transition from pore waters to surface water. Taking the medians as robust estimates for average concentrations, surface water concentrations of DOC and iron were about $68 \%$ and $81 \%$ lower than in pore water, respectively. This may also be caused by a simple dilution effect of wetland pore water with groundwater, though. This could not be ruled out based on the available data, as $\delta^{18} \mathrm{O}$ and $\delta^{2} \mathrm{H}$ of shallow wetland groundwater and deep groundwater were not sufficiently different and also chloride could not be used (not shown), but a major contribution of water originating from wetland areas during storm events was already stated by Lischeid et al. (2007). Nevertheless, one could expect a formation of a relatively iron enriched flocculation or precipitation product, as has been observed at the site in form of iron rich colloids (Neubauer et al., 2012, unpublished). An enrichment of iron at the transition from anoxic to oxic conditions was also observed for the capillary fringe of wetlands (Küsel et al., 2008; Knorr et al., 2009; Biester et al., 2012). Moreover, an expected stoichiometric ratio of such a flocculation product, with iron to carbon ranging from 0.05 to 0.07 would coincide well with iron to carbon ratios in the peat at capillary fringe at this particular site (based on data from Blodau et al., 2008; Goldberg et al., 2008). Iron was also found to be the most prominent metal cation present in the peat besides iron (Knorr, 2010, unpublished). Of course, such iron to carbon ratios are lower than ratios observed for DOC flocculation in surface waters (McKnight et al., 1992) or sorption in mineral soils (Eusterhues et al., 2011; Mikutta and Kaiser, 2011) and, thus, it may be a combination of different effects. Nevertheless, as iron(III) salts are known as effective flocculants for DOC (Lefebvre and Legube, 1993), this flocculation and precipitation may at least partly be explained by an oxidation of ferrous to ferric iron and subsequent flocculation of DOC. Compared to aluminum, iron(III) salts also proved to be more effective for humic acid removal especially at $\mathrm{pH}$ values below 4 (Libecki and Dziejowski, 2008), which is why we believe that the flocculation is mainly initiated by iron. Moreover, the oxidation of ferrous to ferric iron leads to the formation of ferric hydroxides and dissolved complexes with hydroxyl ligands with a subsequent drop in $\mathrm{pH}$, i.e., ferric iron is a strong cationic acid (Stumm and Morgan, 1996). Therefore, oxidation and subsequent flocculation by ferric iron could also explain the observed drop in $\mathrm{pH}$ during phases of high discharge and high DOC, as the anaerobic pore waters in the wetlands did not show much lower $\mathrm{pH}$ than the surface waters (Table 1). The observed change in $\mathrm{pH}$ due to oxidation of iron, but also of sulfides may, therefore, be an additional factor affecting DOC flocculation, as DOC solubility depends also on pH (Clark et al., 2005, 2012; Grybos et al., 2009). Aluminum, on the other hand, does not change in redox state during transition from anaerobic to aerobic waters has, thus, no effect on $\mathrm{pH}$. Moreover, concentrations in the pore water were also much higher than in the surface water and did obviously not affect DOC mobilisation. Though, a contribution of aluminum to DOC flocculation cannot be excluded.

Along with the observed differences in concentrations of solutes in the compartments wetland pore water, groundwater and surface water, it was obvious that ionic strengths in the wetland pore waters may exceed ionic strength in the surface 
waters by far. Thus, while for surface waters ionic strength was found to negatively affect solubility of DOC (Hruska et al., 2009), this relation is more or less reversed in pore waters, where DOC concentrations were found to increase almost infinitely along with ferrous iron concentrations not only in this study (Table 3, Fig. 5) (Grybos et al., 2009; Zak and Gelbrecht, 2007).

\subsection{Pore water biogeochemistry and associated DOC dynamics}

Many studies found support that the decline in sulfate deposition can explain increases in the release of DOC into streams to a large extent (Evans et al., 2006). Nevertheless, this relation was not universal, also in catchments with peat soils (Clark et al., 2010; Worrall and Burt, 2007). Therefore, the effects of sulfate addition into wetlands will be briefly outlined in the following. While sulfate is the anion of a strong acid and, thus, does not affect $\mathrm{pH}$ in the transition from pore or ground water into surface water, it can be used as an electron acceptor for anaerobic respiration in wetlands (Keller and Bridgham, 2007; Limpens et al., 2008; Pester et al., 2012) and sulfate reduction will increase $\mathrm{pH}$ here by consumption of acidity (Stumm and Morgan, 1996). Thus, addition of sulfate to wetlands could be expected to increase anaerobic respiration by increasing sulfate reduction, as e.g., observed after droughts (e.g., Knorr et al., 2009) and for sulfate deposition experiments (e.g., Gauci and Chapman, 2006). From these considerations one may even postulate an increase of DOC production under elevated sulfate deposition onto wetlands due to increased availability of electron acceptors for respiratory breakdown of solid organic matter and subsequent increases in $\mathrm{pH}$, which further supports microbial activity.

This outlined process pattern would be in line with the observed negative correlation of sulfate and DOC in the wetland pore water. On a mechanistic level, DOC can be expected to be released under iron and sulfate reducing conditions and concomitant increases in $\mathrm{pH}$, probably due to reductive dissolution of iron oxides and release of associated DOC (Zak and Gelbrecht, 2007). Also in the surface water a slightly negative correlation of sulfate and DOC was observed for the summer months (Fig. 6), when reducing processes and, thus, also sulfate reduction are more intense than in winter (see also Fig. 4 for seasonal dynamics of reducing conditions from spring to summer). In contrast to the pore water, in the case of discharge the analysis of the hydrograph and the separation of sources based on event water contributions demonstrated that this inverse relation can be explained by the fact that sulfate and DOC have different hydrological sources, at least in summer: waters of high DOC concentrations and due to reducing conditions low in or devoid of sulfate were released from the wetland waters (wetland pore water, shallow wetland groundwater) during discharge events, while during these events the contribution of deeper groundwater - as the main source of sulfate - decreased. Only during winter months, DOC and sulfate correlated in a positive manner, probably due to changes in hydrological flow paths (e.g., more surface flow components), less activity of reductive processes and also reduced plant uptake (Bartlett et al., 2009). On the other hand there was a strong positive correlation of DOC and iron in pore water, groundwater, and surface water. The detailed pore water investigations of this and former studies (Knorr et al., 2009; Blodau et al., 2008) support the hypothesis, that DOC was predominantly released during phases of iron reducing activity (e.g., Fig. 5). Although iron and DOC concentrations seemed to sharply decline during the transition from pore to surface water, this strong correlation remained with higher iron concentrations at higher DOC concentrations in the discharge, especially at shallow groundwater table levels favouring reducing conditions (Fig. 6).

Thus, there is a good understanding of DOC mobilisation in the pore water and export paths via different flow paths and sources for the catchment under study and these processes probably apply to a number of other sites as well (Morel et al., 2009; McGlynn and McDonnell, 2003; Seibert et al., 2009; Clark et al., 2012). While the effect of acid and/or sulfate deposition on catchment DOC export has been demonstrated for many sites and may be responsible for a large part of the observed long-term trends (e.g., reviewed in Clark et al., 2010), the process based understanding from this study adds another potential factor to cause increased DOC exports from catchments. Due to the tight coupling of DOC and iron dynamics and due to the high release of DOC under reducing conditions in wetlands (Zak and Gelbrecht, 2007; Grybos et al., 2009), an increase in iron reducing activity or an increase in reducing conditions and associated increases in $\mathrm{pH}$ causing higher DOC mobility and higher microbial activity in general would also explain rising DOC and iron concentrations in catchment exports in a long-term perspective (Kritzberg and Ekström, 2012). Higher microbial activity and higher iron reduction could e.g., be caused by increased temperatures due to climate change (e.g., temperature relationships reported in Winterdahl et al., 2011; Köhler et al., 2008), as depicted for the site under study here in Fig. 2, or due to increased wetness as a result of changed precipitation patterns (e.g., changes in hydrology reported in Seibert et al., 2009; Köhler et al., 2008). Furthermore, reduced inputs of sulfate and nitrate could shift anaerobic respiration towards iron reduction and, thereby, increase the release of iron oxide-bound organic matter (Bottrell, 2012). Via the formation of iron sulfides, iron dynamics is further closely linked to sulfate reduction and sulfide oxidation (Knorr et al., 2009; Bottrell et al., 2007). Moreover, more frequent drought and rewetting events could stimulate anaerobic mineralisation by regeneration of electron acceptors, as has been demonstrated for laboratory and field experiments (Knorr et al., 2008, 2009; Deppe et al., 2010; Blodau and Moore, 2003). Although we could not identify changes in hydrological conditions based 
on trend analysis of discharge from the site under study here and an indirect mechanistic link of sulfate loadings interacting with iron cycling cannot be ruled out, a combination of several of the outlined effects may be likely.

\section{Conclusions}

In summary, this study demonstrated that for an understanding of increasing DOC exports from catchments, besides the accepted effects of acid rain deposition, processes within the source areas (i.e., the wetlands), processes during the transition from the source to the receiving stream (during which a large fraction of DOC is captured), and the impact of different hydrological and biogeochemical preconditions have to be considered. DOC concentrations in pore and surface waters were strongly and linearly correlated with iron, supporting the hypothesis that iron redox dynamics exerts a major control on DOC mobilisation. Also increases in $\mathrm{pH}$ under reducing conditions may have exerted a positive feedback mechanism on DOC solubilisation. On the other hand, ionic strength in the pore waters exceeded ionic strength in surface waters by far and, thus, did not limit DOC solubility. The importance of redox conditions in the wetlands was further demonstrated by the observed dependence of nitrate and sulfate concentration on pre-event groundwater table levels. Our observations of opposing relationships of DOC with $\mathrm{pH}$ or $\mathrm{pH}$ with sulfate in pore water of wetlands and adjacent streams underscore the importance of considering biogeochemical processes and hydrological flow paths leading to these observed signals. Although such a statement cannot be verified yet, an alternative hypothesis for increased DOC exports from catchments in the long term could be an increase of DOC release from wetland source areas by increased reductive processes, associated release of DOC from reductively dissolved iron oxides, and generally increased mineralisation and DOC production by increased $\mathrm{pH}$. This stimulation of DOC release could potentially be driven by increasing temperatures due to global warming, by changes in precipitation patterns, or by a shift from sulfate polluted systems dominated by sulfate reduction to iron dominated systems favouring reductive dissolution of iron phases as sulfate loads decrease.

Acknowledgements. This study was in part supported by a Deutsche Forschungsgemeinschaft (DFG) grant to C. Blodau (BL 563/7), and by a grant of the Bavarian Environmental Authority (Landesamt für Umwelt, LFU, Hof) to Egbert Matzner, Stefan Peiffer, and Jan Fleckenstein. Long-term data of the LFU was pre-processed by Martin Reichert and Stefan Strohmeier. Stable Isotope measurements were conducted at the BayCEER Laboratory of Isotope-Biogeochemistry, headed by Gerhard Gebauer. Air temperature data was kindly provided by the department of Micrometeorology (Thomas Foken, Johannes Lüers, and Johannes Olesch). The assistance of the laboratory staff of the Department of Hydrology and MSc Martin Reichert for analytical work, of BSc
Sarah Hofmann for fluorescence analysis, of Jürgen Leonbacher and Jürgen Reinhard for sampling, and of Gunnar Lischeid for help with trend analysis in $\mathrm{R}$ is greatly acknowledged. Comments of two anonymous reviewers and of Simon Bottrell significantly improved the first version of this manuscript. This publication was funded by the German Research Foundation (DFG) and the University of Bayreuth in the funding programme for Open Access Publishing.

Edited by: B. A. Bergamaschi

\section{References}

Austnes, K., Evans, C., Eliot-Laize, C., Naden, P., and Old, G.: Effects of storm events on mobilisation and in-stream processing of dissolved organic matter (dom) in a welsh peatland catchment, Biogeochemistry, 99, 157-173, doi:10.1007/s10533-0099399-4, 2010.

Bartlett, R., Bottrell, S., Coulson, J., Lee, J., and Forbes, L.: 34s tracer study of pollutant sulfate behaviour in a lowland peatland, Biogeochemistry, 95, 261-275, doi:10.1007/s10533-009-93357, 2009

Biester, H., Hermanns, Y.-M., and Cortizas, A. M.: The influence of organic matter decay on the distribution of major and trace elements in ombrotrophic mires - a case study from the harz mountains, Geochim. Cosmochim. Acta, 84, 126-136, 2012.

Billett, M. F., Palmer, S. M., Hope, D., Deacon, C., StoretonWest, R., Hargreaves, K. J., Flechard, C., and Fowler, D.: Linking land-atmosphere-stream carbon fluxes in a lowland peatland system, Glob. Biogeochem. Cycles, 18, GB1024, doi:10.1029/2003gb002058, 2004.

Billett, M. F., Deacon, C. M., Palmer, S. M., Dawson, J. J. C., and Hope, D.: Connecting organic carbon in stream water and soils in a peatland catchment, J. Geophys. Res., 111, 2010-2010, 2006.

Bishop, K., Seibert, J., Köhler, S., and Laudon, H.: Resolving the double paradox of rapidly mobilized old water with highly variable responses in runoff chemistry, Hydrol. Process., 18, 185189, 2004.

Blodau, C. and Moore, T. R.: Experimental response of peatland carbon dynamics to a water table fluctuation, Aq. Sci., 65, 4762, 2003.

Blodau, C., Fulda, B., Bauer, M., and Knorr, K.-H.: Arsenic speciation and turnover in intact organic soil mesocosms during experimental drought and rewetting, Geochim. Cosmochim. Acta, 72, 3991-4007, 2008.

Bottrell, S.: Interactive comment on "doc-dynamics in a small headwater catchment as driven by redox fluctuations and hydrological flow paths - are doc exports mediated by iron reduction/oxidation cycles?" by Knorr, K.-H., Biogeosciences Discuss., 9, C5515-C5517, 2012.

Bottrell, S. H., Mortimer, R. J. G., Spence, M., Krom, M. D., Clark, J. M., and Chapman, P. J.: Insights into redox cycling of sulfur and iron in peatlands using high-resolution diffusive equilibrium thin film (det) gel probe sampling, Chem. Geol., 244, 409-420, doi:10.1016/j.chemgeo.2007.06.028, 2007.

Clark, J. M., Chapman, P. J., Adamson, J. K., and Lane, S. N.: Influence of drought-induced acidification on the mobility of dissolved organic carbon in peat soils, Global Change Biol., 11, 791-809, 2005.

Clark, J. M., Lane, S. N., Chapman, P. J., and Adamson, J. K.: Link between doc in near surface peat and stream wa- 
ter in an upland catchment, Sci. Total Environ., 404, 308-315, doi:10.1016/j.scitotenv.2007.11.002, 2008.

Clark, J. M., Bottrell, S. H., Evans, C. D., Monteith, D. T., Bartlett, R., Rose, R., Newton, R. J., and Chapman, P. J.: The importance of the relationship between scale and process in understanding long-term doc dynamics, Sci. Total Environ., 408, 2768-2775, 2010.

Clark, J. M., Heinemeyer, A., Martin, P., and Bottrell, S. H.: Processes controlling doc in pore water during simulated drought cycles in six different uk peats, Biogeochemistry, 109, 253-270, doi:10.1007/s10533-011-9624-9, 2012.

Cory, R. M. and McKnight, D. M.: Fluorescence spectroscopy reveals ubiquitous presence of oxidized and reduced quinones in dissolved organic matter, Environ. Sci. Technol., 39, 8142-8149, 2005.

Deppe, M., Knorr, K.-H., McKnight, D., and Blodau, C.: Effects of short-term drying and irrigation on $\mathrm{CO}_{2}$ and $\mathrm{CH}_{4}$ production and emission from mesocosms of a northern bog and an alpine fen, Biogeochemistry, 100, 89-103, doi:10.1007/s10533-010-94069, 2010.

Diehl, A. C., Speitel, G. E., Symons, J. M., Krasner, S. W., Hwang, S. J., and Barrett, S. E.: Dbp formation during chloramination, J. Am. Water Work Assoc., 92, 76-90, 2000.

Driscoll, C. T., Lehtinen, M. D., and Sullivan, T. J.: Modeling the acid-base chemistry of organic solutes in adirondack, new york, lakes, Water Resour. Res., 30, 297-306, doi:10.1029/93wr02888, 1994.

Eusterhues, K., Rennert, T., Knicker, H., Kogel-Knabner, I., Totsche, K. U., and Schwertmann, U.: Fractionation of organic matter due to reaction with ferrihydrite: Coprecipitation versus adsorption, Environ. Sci. Technol., 45, 527-533, doi:10.1021/es1023898, 2011.

Evans, C. and Davies, T. D.: Causes of concentration/discharge hysteresis and its potential as a tool for analysis of episode hydrochemistry, Water Resour. Res., 34, 129-137, doi:10.1029/97wr01881, 1998.

Evans, C. D., Chapman, P. J., Clark, J. M., Monteith, D. T., and Cresser, M. S.: Alternative explanations for rising dissolved organic carbon export from organic soils, Global Change Biol., 12, 2044-2053, 2006.

Fellman, J. B., Hood, E., Edwards, R. T., and D'Amore, D. V.: Changes in the concentration, biodegradability, and fluorescent properties of dissolved organic matter during stormflows in coastal temperate watersheds, J. Geophys. Res., 114, G01021, doi:10.1029/2008jg000790, 2009.

Frei, S., Lischeid, G., and Fleckenstein, J. H.: Effects of microtopography on surface - subsurface exchange and runoff generation in a virtual riparian wetland - a modeling study, Adv. Water Resour., 33, 1388-1401, doi:10.1016/j.advwatres.2010.07.006, 2010.

Gauci, V. and Chapman, S. J.: Simultaneous inhibition of ch4 efflux and stimulation of sulphate reduction in peat subject to simulated acid rain, Soil Biol. Biochem., 38, 3506-3510, 2006.

Gerstberger, P.: Waldökosystemforschung in Nordbayern: Die Bitök-Untersuchungsflächen im Fichtelgebirge und Steigerwald, in: Bayreuther forum ökologie, Bayreuth, Germany, 1-91, 2001.

Glatzel, S., Kalbitz, K., Dalva, M., and Moore, T.: Dissolved organic matter properties and their relationship to carbon dioxide efflux from restored peat bogs, Geoderma, 113, 397-411, 2003.
Goldberg, S. D., Knorr, K. H., and Gebauer, G.: $\mathrm{N}_{2} \mathrm{O}$ concentration and isotope signature along profiles provide deeper insight into the fate of $\mathrm{N}_{2} \mathrm{O}$ in soils, Isot. Environ. Healt. S., 44, 377-391, 2008.

Goldberg, S. D., Knorr, K.-H., Blodau, C., Lischeid, G., and Gebauer, G.: Impact of altering the water table height of an acidic fen on $\mathrm{N}_{2} \mathrm{O}$ and $\mathrm{NO}$ fluxes and soil concentrations, Global Change Biol., 16, 220-233, doi:10.1111/j.13652486.2009.02015.x, 2010.

Grybos, M., Davranche, M., Gruau, G., Petitjean, P., and Pédrot, M.: Increasing ph drives organic matter solubilization from wetland soils under reducing conditions, Geoderma, 154, 13-19, 2009.

Haaland, S., Hongve, D., Laudon, H., Riise, G., and Vogt, R. D.: Quantifying the drivers of the increasing colored organic matter in boreal surface waters, Environ. Sci. Technol., 44, 2975-2980, doi:10.1021/es903179j, 2010.

Hiraide, M.: Heavy metals complexed with humic substances in fresh-water, Anal. Sci., 8, 453-459, doi:10.2116/analsci.8.453, 1992.

Hruška, J., Laudon, H., Johnson, C. E., Köhler, S., and Bishop, K.: Acid/base character of organic acids in a boreal stream during snowmelt, Water Resour. Res., 37, 1043-1056, 2001.

Hruska, J., Kram, P., McDowell, W. H., and Oulehle, F.: Increased dissolved organic carbon (doc) in central european streams is driven by reductions in ionic strength rather than climate change or decreasing acidity, Environ. Sci. Technol., 43, 4320-4326, doi:10.1021/es803645w, 2009.

Inamdar, S., Finger, N., Singh, S., Mitchell, M., Levia, D., Bais, H., Scott, D., and McHale, P.: Dissolved organic matter (dom) concentration and quality in a forested mid-atlantic watershed, USA, Biogeochemistry, 108, 55-76, doi:10.1007/s10533-011-9572-4, 2012.

Keller, J. K. and Bridgham, S. D.: Pathways of anaerobic carbon cycling across an ombrotrophic-minerotrophic peatland gradient, Limnol. Oceanogr., 52, 96-107, 2007.

Knorr, K. H., Oosterwoud, M., and Blodau, C.: Experimental drought alters rates of soil respiration and methanogenesis but not carbon exchange in soil of a temperate fen, Soil Biol. Biochem., 40, 1781-1791, doi:10.1016/j.soilbio.2008.03.019, 2008.

Knorr, K. H., Lischeid, G., and Blodau, C.: Dynamics of redox processes in a minerotrophicfen exposed to a water table manipulation, Geoderma, 153, 379-392, doi:10.1016/j.geoderma.2009.08.023, 2009.

Köhler, S., Buffam, I., Laudon, H., and Bishop, K.: Climate's control of intra-annual and interannual variability of total organic carbon concentration and flux in two contrasting boreal landscape elements, J. Geophys. Res, 113, G03012, doi:10.1029/2007JG000629, 2008.

Kritzberg, E. S. and Ekström, S. M.: Increasing iron concentrations in surface waters - a factor behind brownification?, Biogeosciences, 9, 1465-1478, doi:10.5194/bg-9-1465-2012, 2012.

Küsel, K., Blöthe, M., Schulz, D., Reiche, M., and Drake, H. L.: Microbial reduction of iron and porewater biogeochemistry in acidic peatlands, Biogeosciences, 5, 1537-1549, doi:10.5194/bg5-1537-2008, 2008

Laudon, H., Berggren, M., Agren, A., Buffam, I., Bishop, K., Grabs, T., Jansson, M., and Köhler, S.: Patterns and dynamics of dissolved organic carbon (doc) in boreal streams: The role of 
processes, connectivity, and scaling, Ecosystems, 14, 880-893, doi:10.1007/s10021-011-9452-8, 2011.

Lefebvre, E. and Legube, B.: Coagulation-flocculation by ferric chloride of some organic compounds in aqueous solution, Water Res., 27, 433-447, 1993.

Libecki, B. and Dziejowski, J.: Optimization of humic acids coagulation with aluminum and iron(iii) salts, Pol. J. Environ. Stud., 17, 397-403, 2008.

Limpens, J., Berendse, F., Blodau, C., Canadell, J. G., Freeman, C., Holden, J., Roulet, N., Rydin, H., and Schaepman-Strub, G.: Peatlands and the carbon cycle: from local processes to global implications - a synthesis, Biogeosciences, 5, 1475-1491, doi:10.5194/bg-5-1475-2008, 2008.

Lischeid, G.: Investigating trends of hydrochemical time series of small catchments by artificial neural networks, Physics and Chemistry of the Earth, Part B: Hydrology, Oceans and Atmosphere, 26, 15-18, doi:10.1016/s1464-1909(01)85007-3, 2001a.

Lischeid, G.: Investigating short-term dynamics and long-term trends of so4 in the runoff of a forested catchment using artificial neural networks, J. Hydrol., 243, 31-42, doi:10.1016/s00221694(00)00399-1, 2001b.

Lischeid, G., Kolb, A., and Alewell, C.: Apparent translatory flow in groundwater recharge and runoff generation, J. Hydrol., 265, 195-211, doi:10.1016/s0022-1694(02)00108-7, 2002.

Lischeid, G., Kolb, A., Alewell, C., and Paul, S.: Impact of redox and transport processes in a riparian wetland on stream water quality in the fichtelgebirge region, southern germany, Hydrol. Process., 21, 123-132, 2007.

Matzner, E.: Biogeochemistry of forested catchments in a changing environment - a german case study, in: Ecological studies, edited by: Baldwin, I. T., Caldwell, M. M., Heldmaier, G., Jackson, R. B., Lange, O. L., Mooney, H. A., Schulze, E.-D., and Sommer, U., Springer, Heidelberg, Germany, 2004.

Maxin, C. R. and Kögel-Knabner, I.: Partitioning of polycyclic aromatic hydrocarbons (pah) to water-soluble organic matter, Eur. J. Soil Sci., 46, 193-204, doi:10.1111/j.13652389.1995.tb01827.x, 1995.

McDowell, W. H.: Dissolved organic matter in soils - future directions and unanswered questions, Geoderma, 113, 179-186, doi:10.1016/s0016-7061(02)00360-9, 2003.

McGlynn, B. L. and McDonnell, J. J.: Role of discrete landscape units in controlling catchment dissolved organic carbon dynamics, Water Resour. Res., 39, 1090, doi:10.1029/2002wr001525, 2003.

McKnight, D. M., Bencala, K. E., Zellweger, G. W., Aiken, G. R., Feder, G. L., and Thorn, K. A.: Sorption of dissolved organic carbon by hydrous aluminum and iron oxides occurring at the confluence of deer creek with the snake river, summit county, colorado, Environ. Sci. Technol., 26, 1388-1396, doi:10.1021/es00031a017, 1992.

Mikutta, R. and Kaiser, K.: Organic matter bound to mineral surfaces: Resistance to chemical and biological oxidation, Soil Biol. Biochem., 43, 1738-1741, doi:10.1016/j.soilbio.2011.04.012, 2011.

Monteith, D. T., Stoddard, J. L., Evans, C. D., de Wit, H. A., Forsius, M., Hogasen, T., Wilander, A., Skjelkvale, B. L., Jeffries, D. S., Vuorenmaa, J., Keller, B., Kopacek, J., and Vesely, J.: Dissolved organic carbon trends resulting from changes in atmospheric deposition chemistry, Nature, 450, 537-540, 2007.
Morel, B., Durand, P., Jaffrezic, A., Gruau, G., and Molenat, J.: Sources of dissolved organic carbon during stormflow in a headwater agricultural catchment, Hydrol. Process., 23, 2888-2901, doi:10.1002/hyp.7379, 2009.

Muhr, J., Franke, J., and Borken, W.: Drying-rewetting events reduce $\mathrm{c}$ and $\mathrm{n}$ losses from a norway spruce forest floor, Soil Biol. Biochem., 42, 1303-1312, doi:10.1016/j.soilbio.2010.03.024, 2010.

Murphy, K. R., Butler, K. D., Spencer, R. G. M., Stedmon, C. A., Boehme, J. R., and Aiken, G. R.: Measurement of dissolved organic matter fluorescence in aquatic environments: An interlaboratory comparison, Environ. Sci. Technol., 44, 9405-9412, doi:10.1021/es102362t, 2010.

Peiffer, S., Walton-Day, K., and Macalady, D.: The interaction of natural organic matter with iron in a wetland (tennessee park, colorado) receiving acid mine drainage, Aq. Geochem., 5, 207 223, doi:10.1023/a:1009617925959, 1999.

Pester, M., Knorr, K.-H., Friedrich, M. W., Wagner, M., and Loy, A.: Sulfate-reducing microorganisms in wetlands - fameless actors in carbon cycling and climate change, Front. Microbiol., 3, 72, doi:10.3389/fmicb.2012.00072, 2012.

Roulet, N. and Moore, T. R.: Environmental chemistry: Browning the waters, Nature, 444, 283-284, 2006.

Schilli, C., Lischeid, G., and Rinklebe, J.: Which processes prevail?: Analyzing long-term soil solution monitoring data using nonlinear statistics, Geoderma, 158, 412-420, doi:10.1016/j.geoderma.2010.06.014, 2010.

Seibert, J., Grabs, T., Köhler, S., Laudon, H., Winterdahl, M., and Bishop, K.: Linking soil- and stream-water chemistry based on a Riparian Flow-Concentration Integration Model, Hydrol. Earth Syst. Sci., 13, 2287-2297, doi:10.5194/hess-13-22872009, 2009.

Stedmon, C. A. and Bro, R.: Characterizing dissolved organic matter fluorescence with parallel factor analysis: A tutorial, Limnol. Oceanogr. Methods, 6, 572-579, 2008.

Stumm, W. and Morgan, J. J.: Aquatic chemistry - chemical equilibria and rates in natural waters, Environ. Sci. Technol., edited by: Schnoor, J. L. and Zehnder, A., Wiley-Interscience, New York, USA, 1021, 425-513, 1996.

Tamura, H., Goto, K., Yotsuyanagi, T., and Nagayama, M.: Spectrophotometric determination of iron(ii) with 1, 10phenanthroline in the presence of large amounts of iron(iii), Talanta, 21, 314-318, 1974.

Winterdahl, M., Futter, M., Köhler, S., Laudon, H., Seibert, J., and Bishop, K.: Riparian soil temperature modification of the relationship between flow and dissolved organic carbon concentration in a boreal stream, Water Resour. Res., 47, W08532, doi:10.1029/2010wr010235, 2011.

Worrall, F. and Burt, T. P.: Trends in doc concentration in great britain, J. Hydrol., 346, 81-92, 2007.

Worrall, F., Burt, T., and Adamson, J.: Can climate change explain increases in doc flux from upland peat catchments?, Science of the Total Environment, 326, 95-112, 2004.

Worrall, F., Gibson, H. S., and Burt, T. P.: Production vs. Solubility in controlling runoff of doc from peat soils - the use of an event analysis, J. Hydrol., 358, 84-95, 2008.

Zak, D. and Gelbrecht, J.: The mobilisation of phosphorus, organic carbon and ammonium in the initial stage of fen rewetting (a case study from ne germany), Biogeochemistry, 85, 141-151, 2007. 